University of Nebraska - Lincoln

DigitalCommons@University of Nebraska - Lincoln

Agronomy \& Horticulture - Faculty Publications

Agronomy and Horticulture Department

1987

\title{
Combining Ability Effects for Mineral Elements in Forage Sorghum Hybrids
}

\author{
H. J. Gorz \\ University of Nebraska-Lincoln \\ Francis A. Haskins \\ University of Nebraska-Lincoln, fhaskins@neb.rr.com \\ Jeffrey F. Pedersen \\ University of Nebraska-Lincoln, jpedersen1@unl.edu \\ W. M. Ross \\ USDA-ARS
}

Follow this and additional works at: https://digitalcommons.unl.edu/agronomyfacpub

Part of the Plant Sciences Commons

Gorz, H. J.; Haskins, Francis A.; Pedersen, Jeffrey F.; and Ross, W. M., "Combining Ability Effects for Mineral Elements in Forage Sorghum Hybrids" (1987). Agronomy \& Horticulture -- Faculty Publications. 283.

https://digitalcommons.unl.edu/agronomyfacpub/283

This Article is brought to you for free and open access by the Agronomy and Horticulture Department at DigitalCommons@University of Nebraska - Lincoln. It has been accepted for inclusion in Agronomy \& Horticulture -Faculty Publications by an authorized administrator of DigitalCommons@University of Nebraska - Lincoln. 


\title{
Combining Ability Effects for Mineral Elements in Forage Sorghum Hybrids ${ }^{1}$
}

\author{
H. J. Gorz, F. A. Haskins, J. F. Pedersen, and W. M. Ross ${ }^{2}$
}

\begin{abstract}
The concentrations of minerals in forages are important in satisfying animal requirements, but little attention has been given to determining these concentrations in forage sorghum [Sorghum bicolor (L.) Moench.] breeding programs. In this 2-yr study, the objectives were to determine the contents, genetic variability, combining ability effects, and correlations for 12 mineral elements in 49 experimental hybrids of forage sorghum. Mineral elements studied were $\mathrm{N}, \mathrm{Mg}, \mathrm{Si}, \mathrm{P}, \mathrm{S}, \mathrm{Cl}, \mathrm{K}, \mathrm{Ca}, \mathrm{Mn}, \mathrm{Fe}, \mathrm{Cu}$, and $\mathrm{Zn}$. General combining ability (GCA) effects exceeded specific combining ability (SCA) effects for all elements except $\mathrm{P}, \mathrm{Cl}$, and $\mathrm{Fe}$ in females, and $\mathrm{S}$ and $\mathrm{Cl}$ in males. The GCA and SCA effects in females were low for both $\mathrm{Fe}$ and $\mathrm{Cu}$. Genetic ratios. resembling heritability, were higher for GCA than SCA except for $\mathrm{Cl}$ and $\mathrm{Fe}$ in females, and $\mathrm{S}$ and $\mathrm{Cl}$ in males. Thirty phenotypic correlations among the 12 elements were statistically significant. Some of the highest values were from the relationships of $\mathrm{N}$ with $\mathrm{P}, \mathrm{S}, \mathrm{Cu}$, and $\mathrm{Zn} ; \mathrm{Mg}$ with $\mathrm{Si}$ and $\mathrm{Cu}$; Si with $\mathrm{Ca}$; $P$ with $\mathrm{Cu}$ and $\mathrm{Zn} ; \mathrm{S}$ with $\mathrm{K}$; and $\mathrm{Cu}$ with $\mathrm{Zn}$. Some of the highest phenotypic correlations calculated among the mineral elements and 12 agronomic and quality traits were the positive association of protein with $P$, and the negative relationship of height with $N$ and $P$, Brix of stem juice with $K$, and neutral detergent fiber with P. Data obtained in these studies show the feasibility of altering the mineral content of forage sorghum by breeding.
\end{abstract}

Additional index words: Sorghum bicolor (L.) Moench, Heritability, Forage quality, Mineral nutrition, Mineral accumulation, Animal nutrition.

$\mathrm{F}^{\mathrm{o}}$ ORAGE sorghum hybrids [Sorghum bicolor (L.) Moench] are commonly grown in areas where rainfall is insufficient for corn (Zea mays L.) production and may be utilized as silage, greenchop, pasture, or dry hay or fodder. Little attention has been given to mineral concentration of the forage in sorghum breeding programs because the attributes normally emphasized are agronomic performance, adaptation,

\footnotetext{
' Contribution from the USDA-ARS, and the Nebraska Agric. Res. Div., Lincoln, NE 68583. Published as Paper no. 8064, Journal Series, Nebraska Agric. Res. Div. Research was conducted under Project 12-114. Received 23 May 1986.

Supervisory research geneticist, USDA-ARS, Lincoln, NE; George Holmes professor of agronomy, Univ. of Nebraska, Lincoln, NE; assistant professor of agronomy, Auburn Univ., Auburn, AL 36849, and research geneticist, USDA-ARS, Lincoln, NE 68583, respectively.

${ }^{3}$ Experimental forage sorghum line.

Published in Crop Sci. 27:216-219 (1987).
}

pest resistance, and quality factors such as protein and digestibility. Nevertheless, the concentrations of various minerals in forages are often important in satisfying animal requirements because forages supply the great majority of the feed units consumed by beef and dairy cattle (Bos taurus) (3). Unfortunately, the mineral composition of plants does not always fulfill the requirements of consuming animals (12). Breeding improved cultivars with higher concentrations of normally deficient elements, or lower concentrations of normally excessive elements, would significantly reduce deviations from animal needs and provide an economical means for improving animal performance. Previous work with several plant species other than sorghum suggested that mineral concentration was at least partially under genetic control and that considerable progress was possible by selecting for either high or low mineral accumulation $(1,2,7)$. The objectives of our study were to determine the contents, genetic variability, combining ability effects, and correlations for 12 mineral elements in 49 experimental hybrids of forage sorghum.

\section{MATERIALS AND METHODS}

The $49 F_{1}$ hybrids used, growing conditions, and harvesting and sampling procedures were described in an earlier paper (10). Pertinent information relative to this study is repeated here. The 49 hybrids were produced by crossing each of seven females ('Redlan', N35, N38, N48, N4692, $\mathrm{KS} 5$, N5013 ${ }^{3}$ ) with each of seven males [Early Hegari-Sart (EH-Sart) ${ }^{3}$, Early Hegari-White Sourless (EH-WS $)^{3}$, Early Hegari-Rox (EH-Rox) ${ }^{3}$, N6229, 'Rox', 'White Collier' (WC), and $\mathrm{H} 60-29^{3}$ ].

The 49 hybrids were grown in a randomized complete block design with three replications at the University of $\mathrm{Ne}$ braska Agricultural Research and Development Center, Mead, in 1979 and 1980 using standard agricultural practices for that area. The plots were established on Sharpsburg silty clay loam (Typic Argiudoll-fine montmorillonitic mesic) for which detailed chemical and physical characterization has been reported (5). The forage sorghum nursery was adjacent to an area where extensive soil fertility studies have shown that the only fertilizer element producing a positive effect on yield was $\mathrm{N}$. Plots were three $9.1-\mathrm{m}$ rows spaced $0.76 \mathrm{~m}$ apart with plants hand-thinned to a spacing of approximately 
Table 1. The GCA effects, significant GCA values, and experimental means and ranges for 12 mineral elements of 49 forage sorghum hybrids grouped by female and male parents, grown at Mead, NE, 1979 and 1980.

\begin{tabular}{|c|c|c|c|c|c|c|c|c|c|c|c|c|}
\hline \multirow[b]{2}{*}{ Group and entry } & \multicolumn{12}{|c|}{ Mineral element } \\
\hline & $\mathbf{N}$ & $\mathbf{M g}$ & $\mathbf{S i}$ & $\mathbf{p}$ & $\mathbf{S}$ & $\mathrm{Cl}$ & $\mathbf{K}$ & $\mathrm{Ca}$ & $\mathrm{Mn}$ & $\mathrm{Fe}$ & $\mathrm{Cu}$ & $\mathrm{Zn}$ \\
\hline & & & & $-\mathrm{g} \mathrm{l}$ & 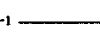 & & & & & $-\mathrm{m}$ & $g^{-1}$ & \\
\hline \multicolumn{13}{|l|}{ Female } \\
\hline N5013 & -0.2 & 0.04 & -1.0 & -0.05 & 0.00 & 0.04 & -0.3 & -0.23 & 0.5 & 6.0 & -0.02 & 0.7 \\
\hline $\mathrm{N} 48$ & -0.4 & -0.03 & -1.4 & -0.07 & -0.06 & -0.15 & -1.5 & $0.17 *$ & -0.1 & -9.2 & -0.04 & -0.6 \\
\hline N4692 & -0.3 & 0.01 & 1.0 & -0.20 & 0.01 & 0.09 & 0.1 & $0.24^{*}$ & 1.3 & 17.0 & -0.04 & -1.0 \\
\hline KS5 & 0.3 & -0.18 & -3.0 & $0.24^{*}$ & 0.03 & -0.12 & 0.6 & -0.06 & -2.4 & 1.2 & 0.08 & $2.7^{*}$ \\
\hline N38 & $<0.1$ & 0.08 & 2.9 & -0.06 & -0.05 & 0.03 & -2.2 & -0.01 & 1.6 & 1.2 & -0.12 & -1.7 \\
\hline N35 & 0.4 & 0.03 & 1.2 & 0.04 & 0.03 & 0.06 & 0.5 & -0.02 & -0.4 & -6.6 & 0.20 & -0.4 \\
\hline Redlan & 0.2 & 0.03 & 0.4 & 0.09 & $0.06 *$ & 0.04 & $2.9^{*}$ & -0.10 & -0.6 & -9.6 & -0.06 & 0.2 \\
\hline Significant value & 0.4 & 0.14 & 2.9 & 0.19 & 0.05 & 0.14 & 1.5 & 0.11 & 2.4 & 19.2 & 0.32 & 1.5 \\
\hline \multicolumn{13}{|l|}{ Male } \\
\hline EH-Sart & -0.8 & -0.30 & -4.7 & -0.40 & -0.05 & -0.05 & 0.1 & -0.33 & -1.7 & -0.1 & -0.92 & -4.3 \\
\hline EH-WS & 0.2 & 0.20 & 3.0 & 0.08 & 0.03 & 0.12 & 1.8 & 0.06 & 0.6 & -1.8 & 0.19 & 1.3 \\
\hline EH-Rox & -0.1 & -0.10 & 1.5 & 0.01 & 0.03 & -0.01 & -0.9 & -0.03 & -0.5 & 6.3 & -0.46 & -1.0 \\
\hline N6229 & -0.7 & -0.06 & -3.7 & -0.28 & 0.01 & -0.12 & 1.9 & -0.23 & -0.8 & -5.2 & -0.47 & -3.1 \\
\hline H60-29 & $1.2^{*}$ & 0.06 & 2.4 & 0.33 & 0.04 & -0.08 & 0.3 & -0.05 & -1.5 & -6.8 & $0.88^{*}$ & 2.3 \\
\hline Rox & 0.4 & 0.17 & 0.9 & 0.18 & 0.01 & 0.15 & -1.1 & $0.31 *$ & -1.0 & 5.1 & 0.18 & $3.8^{*}$ \\
\hline WC & -0.2 & 0.02 & 0.6 & 0.08 & -0.07 & -0.02 & -2.1 & $0.25^{*}$ & $4.9 *$ & 2.5 & $0.59^{*}$ & 1.1 \\
\hline Significant value & 1.1 & 0.26 & 3.9 & 0.41 & 0.08 & 0.41 & 2.1 & 0.07 & 2.3 & 10.5 & 0.58 & 2.9 \\
\hline \multicolumn{13}{|c|}{ Overall mean $\dagger$ and range } \\
\hline Mean & 9.7 & 3.13 & 51.1 & 2.10 & 1.20 & 1.88 & 19.5 & 2.37 & 31.5 & 167.8 & 6.16 & 36.6 \\
\hline Maximum & 11.6 & 3.56 & 59.5 & 2.89 & 1.35 & 3.03 & 26.4 & 3.05 & 43.7 & 208.8 & 7.65 & 43.3 \\
\hline Minimum & 7.9 & 2.72 & 42.9 & 1.48 & 1.05 & 1.50 & 14.7 & 1.80 & 27.4 & 132.2 & 4.60 & 30.2 \\
\hline
\end{tabular}

- Indicates significant GCA positive effects, $\geq$ significant values, by one-tailed $t$ test. Effects in a column do not always sum to zero because of rounding.

$\dagger$ Experimental mean + GCA effect = female mean averaged over males or male mean averaged over females, as appropriate.

$0.15 \mathrm{~m}$. A 4.75-m section of the middle row of each plot was harvested after all entries had reached physiological maturity (24 to 27 Sept. 1979, and 6 and 7 Oct. 1980). A random sample of the harvested material was chopped, mixed, and subsampled for dry matter determination and analyses of quality traits and mineral contents. Samples were dried to constant weight in a forced-air oven at $60^{\circ} \mathrm{C}$, ground in a Wiley ${ }^{4}$ mill to pass a $1-\mathrm{mm}$ screen, and stored at room temperature in plastic vials. The dried and ground samples were analyzed for content of $\mathrm{Mg}, \mathrm{Si}, \mathrm{P}, \mathrm{S}, \mathrm{Cl}, \mathrm{K}, \mathrm{Ca}, \mathrm{Mn}, \mathrm{Fe}, \mathrm{Cu}$, and $\mathrm{Zn}$ by energy-dispersive $\mathrm{x}$-ray fluorescence (EDXRF) as described by Knudsen et al. (8) and $\mathrm{N}$ content was determined by the Kjeldahl procedure (4).

Procedures for data analysis were similar to those described by Ross et al. (13). Analyses of variance (ANOVA) were performed, and tests of significance for hybrid entries, females, males, and females $X$ males for each trait were made by testing these mean squares $(M)$ with their respective year interaction mean squares.

General combining ability (GCA) and specific combining ability (SCA) effects were determined for each trait as follows:

$$
\begin{gathered}
\text { GCA (females) }=\bar{X}_{i}-\bar{Y}, \\
\text { GCA (males) }=\bar{X}_{j}-\bar{Y} \text {, and } \\
\text { SCA (hybrids) }=\bar{X}_{i j}-\bar{X}_{i}-\bar{X}_{j}+\bar{Y},
\end{gathered}
$$

where $\bar{X}_{i}$ is the mean of hybrids with a given female averaged over all replications, years, and males; $\bar{X}_{j}$ is the mean of hybrids with a given male averaged over replications, years, and females; $\bar{X}_{i j}$ is the mean of a given hybrid averaged over replications and years; and $\bar{Y}$ is the experimental mean.

Significance of GCA effects was tested as $t=\mathrm{GCA} / \mathrm{SE}_{\mathrm{gca}}$, where the standard error (SE) is $\left(M_{f y} / r m y\right)^{1 / 2}$ or $\left(M_{m y} / r f y\right)^{1 / 2}$ for females or males, respectively. $M_{f y}$ and $M_{m y}$ are the respective female $X$ year and male $\times$ year mean

\footnotetext{
${ }^{4}$ Names of products are included for the benefit of the reader and do not imply endorsement or preferential treatment by the USDA or the Univ. of Nebraska.
}

squares, which are divided by the number of observations (replications, years, and males or females). Significance of SCA effects for hybrids was tested as $t=\mathrm{SCA} / \mathrm{SE}_{\mathrm{sca}}$, where $\mathrm{SE}$ is $\left(M_{f m y} / r y\right)^{1 / 2}, M_{f m y}$ is the mean square for females $\times$ males $X$ years, and $r y$ is the number of observations. Onetailed $t$ tests were used for testing significance of GCA and SCA effects because interest was confined to positive values.

Genetic ratios, which resemble broad-sense heritabilities, were calculated as $\theta_{f}^{2} / \sigma_{\bar{p}}^{2}, \theta_{m}^{2} / \sigma_{\bar{p}_{m}}^{2}$, and $\theta_{f m}^{2} / \sigma_{\bar{p}}^{2}$, where $\theta_{f}^{2}, \theta_{m}^{2}$, and $\theta_{\text {fin }}^{2}$ are the genetic components for females, males, and females $X$ males, respectively, and $\sigma_{\bar{p}}^{2}$ their respective mean phenotypic variance. Although the genotypes in the experiment were fixed, this statistical treatment supplies useful breeding information.

Phenotypic correlations, with year and replication effects removed, were determined among the 12 elements, as well as among the elements and the 12 agronomic and quality traits determined previously $(9,10)$. Genetic correlations were not determined because of some extremely low, and sometimes negative, genetic component values that would give unrealistic or erroneous correlations. Although phenotypic correlations contain both genetic and environmental influences, they represent the associations actually observed.

\section{RESULTS AND DISCUSSION}

Significant differences among hybrids were found only for $\mathrm{K}, \mathrm{Ca}$, and $\mathrm{Zn}$; among females for $\mathrm{K}$ and $\mathrm{Ca}$; and among males for $\mathrm{Ca}$ and $\mathrm{Cu}$ (data not shown). Computation of GCA effects identified one or more superior female parents for accumulation of $P, S, K$, $\mathrm{Ca}$, and $\mathrm{Zn}$, and one or more superior male parents for accumulation of $\mathrm{N}, \mathrm{Ca}, \mathrm{Mn}, \mathrm{Cu}$, and $\mathrm{Zn}$ (Table 1). This was possible, despite nonsignificance sometimes found in the ANOVA for female or male traits, because the $t$ test measured only positive deviations from zero of all hybrids with a common parent and was only indirectly related to the separation of parental mean differences. Among the female parents, those 
Table 2. Genetic estimates of mineral elements in 49 forage sorghum hybrids.

\begin{tabular}{|c|c|c|c|c|c|c|c|c|c|}
\hline \multirow[b]{2}{*}{ Element } & \multicolumn{6}{|c|}{ Genetic component $\dagger$} & \multicolumn{3}{|c|}{ Genetic ratio $†$} \\
\hline & $\theta_{f}^{\mathbf{2}}$ & $\theta_{m}^{2}$ & $\theta_{f m}^{2}$ & $\sigma_{f y}^{2}$ & $\sigma_{m y}^{2}$ & $\sigma_{f m y}^{2}$ & $\theta_{f}^{2} / \sigma_{\overline{P_{f}}}^{2}$ & $\theta_{m}^{2} / \sigma_{\bar{P}_{m}}^{2}$ & $\theta_{f m}^{2} / \sigma_{\bar{P}_{f m}}$ \\
\hline $\mathrm{N}$ & 4.41 & 14.60 & 2.85 & 0.70 & $55.52^{*}$ & $\ddagger$ & 0.50 & 0.32 & 0.10 \\
\hline $\mathbf{M g}$ & 0.31 & 1.30 & $\ddagger$ & 0.30 & $2.93^{*}$ & 0.82 & 0.39 & 0.42 & $\S$ \\
\hline $\mathrm{Si}$ & 149.41 & 499.36 & 52.63 & 193.71 & $550.36^{*}$ & 225.38 & 0.39 & 0.55 & 0.06 \\
\hline $\mathbf{P}$ & 0.96 & 1.92 & 1.08 & 1.19 & $8.22^{*}$ & $\ddagger$ & 0.44 & 0.29 & 0.25 \\
\hline $\mathbf{S}$ & 0.13 & $\ddagger$ & 0.02 & 0.05 & $0.29^{*}$ & 0.02 & 0.69 & $\S$ & 0.08 \\
\hline $\mathrm{Cl}$ & 0.11 & $\ddagger$ & 1.92 & $\ddagger$ & $7.25^{*}$ & $\ddagger$ & 0.08 & $\S$ & 0.23 \\
\hline $\mathbf{K}$ & $197.66^{*}$ & 94.50 & 62.25 & $70.23^{*}$ & $180.30^{*}$ & 30.98 & 0.74 & 0.43 & 0.27 \\
\hline $\mathrm{Ca}$ & $2.23^{*}$ & $5.35^{*}$ & 0.09 & 0.22 & $\mp$ & $\ddagger$ & 0.91 & 0.98 & 0.05 \\
\hline Mn & 0.40 & 3.96 & $\ddagger$ & $0.94 *$ & 0.80 & $\ddagger$ & 0.20 & 0.72 & $\S$ \\
\hline $\mathrm{Fe}$ & $\ddagger$ & 0.33 & $\ddagger$ & 124.57 & $\ddagger$ & $\ddagger$ & $\S$ & 0.01 & $\S$ \\
\hline $\mathrm{Cu}$ & $<0.01$ & $0.34^{*}$ & $\ddagger$ & $\div$ & $0.09^{*}$ & 0.08 & 0.03 & 0.79 & $\$$ \\
\hline $\mathrm{Zn}$ & 1.72 & 6.67 & $\ddagger$ & $\ddagger$ & $2.84^{*}$ & 2.69 & 0.69 & 0.75 & $\S$ \\
\hline
\end{tabular}

* Indicates significant $(P \leq 0.10)$ mean square value.

$\dagger$ The symbols $\theta_{f}^{2}, \theta_{m}^{2}, \theta_{f m}^{2}, \sigma_{f y}^{2}, \sigma_{m y}^{2}$, and $\sigma_{f m y}^{2}$ refer to the genetic components for females, males, and females $\times$ males, and their year interactions, respectively; $\sigma_{\vec{p}}^{2}$ with subscript refers to the appropriate phenotypic variance.

\# Negative component interpreted as zero.

$\$$ Genetic ratio not calculated because of negative genetic component.

Table 3. Phenotypic correlations among mineral elements in $\mathbf{4 9}$ forage sorghum hybrids.

\begin{tabular}{|c|c|c|c|c|c|c|c|c|c|c|c|}
\hline \multirow[b]{2}{*}{ Element $\dagger$} & \multicolumn{11}{|c|}{ Element $\uparrow$} \\
\hline & $\mathbf{M g}$ & $\mathbf{S i}$ & $\mathbf{P}$ & $\mathbf{S}$ & $\mathrm{Cl}$ & $\mathbf{K}$ & $\mathrm{Ca}$ & Mn & $\mathrm{Fe}$ & $\mathrm{Cu}$ & $\mathrm{Zn}$ \\
\hline $\mathrm{N}$ & $0.45 *$ & $0.49^{*}$ & $0.75^{*}$ & $0.62^{*}$ & 0.06 & 0.11 & 0.24 & -0.17 & -0.05 & $0.61 *$ & $0.62^{*}$ \\
\hline $\mathrm{Mg}$ & & $0.63^{*}$ & $0.42^{*}$ & 0.18 & $0.28^{*}$ & 0.13 & $0.47^{*}$ & $0.29 *$ & 0.01 & $0.53^{*}$ & $0.49^{*}$ \\
\hline $\mathrm{Si}$ & & & $0.30^{*}$ & 0.20 & 0.22 & 0.00 & $0.55^{*}$ & $0.41^{*}$ & 0.21 & $0.45^{*}$ & $0.37 *$ \\
\hline $\mathrm{P}$ & & & & 0.39 * & 0.07 & -0.04 & 0.23 & -0.10 & -0.22 & $0.62^{*}$ & $0.68 *$ \\
\hline $\mathbf{S}$ & & & & & 0.14 & $0.66^{*}$ & -0.08 & $-0.32^{*}$ & 0.02 & 0.21 & $0.30^{*}$ \\
\hline $\mathrm{Cl}$ & & & & & & 0.14 & 0.19 & 0.10 & 0.06 & 0.04 & 0.11 \\
\hline $\mathbf{K}$ & & & & & & & -0.25 & -0.21 & -0.09 & -0.03 & 0.01 \\
\hline $\mathrm{Ca}$ & & & & & & & & $0.43^{*}$ & $0.29^{*}$ & $0.46^{*}$ & $0.49^{*}$ \\
\hline Mn & & & & & & & & & 0.22 & $0.30^{*}$ & 0.10 \\
\hline $\mathrm{Fe}$ & & & & & & & & & & 0.02 & 0.11 \\
\hline $\mathrm{Cu}$ & & & & & & & & & & & $0.66^{*}$ \\
\hline
\end{tabular}

* Values $\leq-0.28$ or $\geq 0.28$ are statistically significant at the 0.05 probability level.

† See Table 1 for units of concentration.

with significant GCA effects included N48 and N4692 for $\mathrm{Ca}$ accumulation, KS5 for $\mathrm{P}$ and $\mathrm{Zn}$, and Redlan for $\mathrm{S}$ and K. Significant GCA effects for male parents included $\mathrm{H} 60-29$ for $\mathrm{N}$ and $\mathrm{Cu}$, Rox for $\mathrm{Ca}$ and $\mathrm{Zn}$, and White Collier for $\mathrm{Ca}, \mathrm{Mn}$, and $\mathrm{Cu}$.

Significant specific combining ability effects among hybrids were obtained for all elements except $\mathrm{N}, \mathrm{Si}$, $\mathrm{K}, \mathrm{Cu}$, and $\mathrm{Zn}$ (data not shown). For each mineral element, the hybrid with the highest content was as follows: N-N38 $\times$ H60-29, Mg-N48 $\times \mathrm{EH}-W \mathrm{~S}, \mathrm{Si}-$ N38 $\times$ EH-WS, P-Redlan $\times$ H60-29, S-N35 $\times$ N6229, Cl-N5013 $\times$ EH-Sart, K-Redlan $\times$ N6229, $\mathrm{Ca}-\mathrm{N} 48 \times \mathrm{WC}, \mathrm{Fe}-\mathrm{N} 4692 \times \mathrm{H} 60-29, \mathrm{Cu}-\mathrm{N} 35 \times$ $\mathrm{H} 60-29$, and $\mathrm{Zn}-\mathrm{KS} 5 \times \mathrm{H} 60-29$. Parents involved in hybrids with the highest accumulation of more than one element were for females: N35, N38, N48, and Redlan; for males: EH-WS, H60-29, N6229, and WC.

Genetic estimates (Table 2) revealed that GCA components exceeded SCA components in value for all elements except $\mathrm{P}, \mathrm{Cl}$, and $\mathrm{Fe}$ in females, and $\mathrm{S}$ and $\mathrm{Cl}$ in males. The genetic ratios generally reflected the findings on GCA and SCA components except that the value for $P$ in females was higher than for females $X$ males. Although several of the genetic components and genetic ratios for both females and males were either nil or very low, the values for the majority of the elements suggest that progress in selecting for high or low accumulation should be possible.

Phenotypic correlations were determined among the 12 elements (Table 3). Thirty of the 66 values were statistically significant at the 0.05 probability level, and 11 of these had $r$ values exceeding 0.50 . All significant $r$ values were positive. Some of the highest values were from the relationships of $\mathrm{N}$ with $\mathrm{P}, \mathrm{S}, \mathrm{Cu}$, and $\mathrm{Zn} ; \mathrm{Mg}$ with $\mathrm{Si}$ and $\mathrm{Cu}$; $\mathrm{Si}$ with $\mathrm{Ca} ; \mathrm{P}$ with $\mathrm{Cu}$ and $\mathrm{Zn} ; \mathrm{S}$ with $\mathrm{K}$; and $\mathrm{Cu}$ with $\mathrm{Zn}$.

Phenotypic correlations also were calculated amon the elements and 12 previously reported $(9,10) \mathrm{ag}$ ronomic and quality traits (Table 4). Of the $67 \mathrm{sig}$. nificant $r$ values, 40 were negative, and only 28 had values $\geq 0.50$. In general, the taller, later-maturing, and higher-yielding genotypes had lower contents of $\mathrm{N}, \mathrm{Mg}, \mathrm{Si}, \mathrm{P}, \mathrm{S}, \mathrm{Cl}, \mathrm{Ca}, \mathrm{Cu}$, and $\mathrm{Zn}$. Higher protein content was positively associated with higher contents of $\mathrm{Mg}, \mathrm{Si}, \mathrm{P}, \mathrm{S}, \mathrm{Cu}$, and $\mathrm{Zn}$; and increased digestibility was related to higher levels of $\mathrm{P}, \mathrm{Ca}, \mathrm{Cu}$, and $\mathrm{Zn}$, and lower levels of.$K$. Among the highest values were the positive association of concentrations of protein and $\mathrm{P}$, and the negative relationships of height with $\mathrm{N}$ and $\mathrm{P}$, Brix of stem juice with $\mathrm{K}$, and neutral detergent fiber with $P$.

The 49 forage sorghum hybrids used in the present study, from which dried samples of freshly harvested forage were analyzed for mineral contents, also were preserved as silage as previously reported (11). Dried and ground samples of the ensiled material were analyzed for mineral contents by EDXRF as described above. The simple correlation coefficients for the relationships of values obtained from fresh-dried samples to those values for ensiled samples based on entry 
Table 4. Phenotypic correlations of mineral element concentrations with previously reported $(9,10)$ agronomic and quality traits in 49 forage sorghum hybrids.

\begin{tabular}{|c|c|c|c|c|c|c|c|c|c|c|c|c|}
\hline \multirow[b]{2}{*}{ Trait } & \multicolumn{12}{|c|}{ Mineral element $\dagger$} \\
\hline & $\mathbf{N}$ & $\mathbf{M g}$ & $\mathrm{Si}$ & $\mathbf{P}$ & $\mathbf{S}$ & $\mathrm{Cl}$ & $\mathbf{K}$ & $\mathrm{Ca}$ & Mn & $\mathbf{F e}$ & $\mathrm{Cu}$ & $\mathrm{Zn}$ \\
\hline Flower date & $-0.58 *$ & $-0.45^{*}$ & $-0.58^{*}$ & $-0.69 *$ & $-0.31 *$ & -0.16 & 0.11 & $-0.44^{*}$ & -0.03 & -0.05 & $-0.49 *$ & $-0.66^{*}$ \\
\hline Height & $-0.73^{*}$ & $-0.49 *$ & $-0.56^{*}$ & $-0.74^{*}$ & $-0.42^{*}$ & -0.07 & 0.01 & $-0.36^{*}$ & 0.08 & 0.25 & $-0.51 *$ & $-0.55^{*}$ \\
\hline Lodging scoret & $-0.32^{*}$ & -0.08 & -0.26 & -0.21 & -0.14 & 0.19 & 0.11 & -0.02 & 0.06 & $0.40^{*}$ & $-0.28^{*}$ & -0.01 \\
\hline Brix of stalk juice $\dagger$ & -0.16 & -0.17 & -0.09 & -0.03 & $-0.53^{*}$ & -0.08 & $-0.71 *$ & $0.29 *$ & $0.37 *$ & 0.21 & 0.18 & 0.13 \\
\hline Head yield & 0.19 & 0.23 & $0.33^{*}$ & 0.25 & $0.28^{*}$ & 0.08 & 0.15 & 0.14 & -0.10 & -0.17 & 0.01 & 0.17 \\
\hline Total yield $\ddagger$ & $-0.69 *$ & $-0.47^{*}$ & $-0.50^{*}$ & $-0.64^{*}$ & $-0.57^{*}$ & $-0.29 *$ & -0.20 & $-0.32^{*}$ & 0.06 & -0.04 & $-0.49^{*}$ & $-0.58^{*}$ \\
\hline Protein & -. & $0.45^{*}$ & $0.49 *$ & $0.75^{*}$ & $0.62^{*}$ & 0.06 & 0.11 & 0.24 & -0.17 & -0.05 & $0.61 *$ & $0.62^{*}$ \\
\hline IVDMD‡\$ & 0.27 & 0.10 & 0.07 & $0.57 *$ & -0.14 & -0.02 & $-0.46^{*}$ & $0.43^{*}$ & 0.17 & -0.09 & $0.46^{*}$ & $0.48^{*}$ \\
\hline NDF $\ddagger 8$ & $-0.42^{*}$ & -0.11 & -0.13 & $-0.74^{*}$ & 0.03 & 0.13 & $0.42^{*}$ & $-0.28^{*}$ & -0.03 & 0.23 & $-0.53^{*}$ & $-0.49^{*}$ \\
\hline ADF $\neq \$$ & $-0.36^{*}$ & -0.08 & -0.15 & $-0.62^{*}$ & 0.14 & 0.19 & $0.49^{*}$ & -0.24 & -0.07 & 0.25 & $-0.45^{*}$ & $-0.38^{*}$ \\
\hline ADL $\$$ & 0.04 & 0.09 & 0.13 & $-0.32^{*}$ & $0.40^{*}$ & 0.26 & $0.50^{*}$ & -0.16 & -0.15 & 0.20 & -0.22 & -0.12 \\
\hline Asht & $0.52^{*}$ & $0.55^{*}$ & $0.55^{*}$ & $0.39 *$ & $0.37^{*}$ & 0.22 & 0.11 & $-0.33^{*}$ & 0.04 & 0.14 & $0.34^{*}$ & $0.33^{*}$ \\
\hline
\end{tabular}

Values $\leq-0.28$ or $\geq 0.28$ are statistically significant at the 0.05 probability level.

† See Table 1 for units of concentration of mineral elements; lodging score was based on a scale of 1 to 10 , with 1 denoting no lodging and 10 indicating complete lodging; Brix was measured as grams of solid in $100 \mathrm{~g}$ of stalk juice.

$\ddagger$ For total plant portions harvested including heads, stems, and leaves.

IVDMD, NDF, ADF, and ADL refer to in vitro dry matter digestibility, neutral detergent fiber, acid detergent fiber, and acid detergent lignin, respectively.

means $(n=49)$ were $0.81,0.64,0.66,0.61,0.78,0.57$, $0.92,0.79,0.55,0.49,0.63$, and 0.86 for $\mathrm{N}, \mathrm{Mg}, \mathrm{Si}, \mathrm{P}$, $\mathrm{S}, \mathrm{Cl}, \mathrm{K}, \mathrm{Ca}, \mathrm{Mn}, \mathrm{Fe}, \mathrm{Cu}$, and $\mathrm{Zn}$, respectively. All $r$ values were significant at the 0.01 level of probability. Means for ensiled samples were generally slightly lower than for fresh-dried samples except that the means for $\mathrm{N}, \mathrm{K}, \mathrm{Fe}$, and $\mathrm{Zn}$ were slightly higher.

Although it is recognized that animal rations usually include a variety of feedstuffs to achieve a better balance of nutrients, it is of interest to compare the mineral contents of the forage sorghum hybrids used in the present study with estimates of animal requirements. Reid and Jung (12) reported that a dairy cow giving 20 to $30 \mathrm{~kg}$ of milk daily requires the following concentrations $\left(\mathrm{mg} \mathrm{kg}^{-1}\right)$ of various elements in the ration: $\mathrm{Mg}, 1000 ; \mathrm{P}, 3500 ; \mathrm{S}, 1000 ; \mathrm{K}, 7000 ; \mathrm{Ca}, 4700$; $\mathrm{Mn}, 20 ; \mathrm{Fe}, 100 ; \mathrm{Cu}, 10$; and $\mathrm{Zn}, 40$. Based on the means reported in Table 1, the forage sorghum hybrids used in this study were deficient in $\mathrm{P}, \mathrm{Ca}, \mathrm{Cu}$, and $\mathrm{Zn}$ and would supply approximately $60,50,60$, and $90 \%$, respectively, of the requirements of a dairy cow. According to Kappel et al. (6), sorghum silage is deficient in $\mathrm{Ca}$ and $\mathrm{P}$. In their study, deficiencies of $\mathrm{Cu}$ and $\mathrm{Mg}$ in dairy rations were identified as the probable cause of an unexplained low fertility in the dairy herds of Louisiana.

Data obtained in these studies show the feasibility of altering the mineral content of forage sorghum by breeding. Before such a breeding program is begun, however, additional sources of sorghum germplasm should be investigated because the number of parents used in the present study was small. In addition, attention should be given to problems associated with attempts to change individual elements, genotype $X$ soil fertility interactions, mineral concentrations of other forages or concentrates that will be fed with the forage sorghum, and the availability to animals of ele- ments whose concentrations are increased by breeding, as discussed by Hill and Jung (2).

\section{REFERENCES}

1. Gorsline, G.W., W.I. Thomas, and D.E. Baker. 1964. Inheritance of $\mathrm{P}, \mathrm{K}, \mathrm{Mg}, \mathrm{Cu}, \mathrm{B}, \mathrm{Zn}, \mathrm{Mn}, \mathrm{Al}$, and $\mathrm{Fe}$ concentrations by corn (Zea mays L.) leaves and grain. Crop Sci. 4:207-210.

2. Hill, R.R., Jr., and G.A. Jung. 1975. Genetic variability for chemical composition of alfalfa. I. Mineral elements. Crop Sci. $15: 652-657$

3. Hodgson, H.J. 1976. Forages, ruminant livestock, and food. BioScience 26:625-630.

4. Horwitz, W. 1960. Official methods of analyses of the A.O.A.C. 9 th ed. Association of Official Agricultural Chemists, Washington, DC.

5. James, H.R., J.V. Drew, and D.T. Lewis. 1972. Soils of the agronomy section Univ. of Nebraska Field Lab. at Mead. Rep. no. 9, Dep. of Agronomy. University of Nebraska-Lincoln.

6. Kappel, L.C., E.B. Morgan, R.H. Ingraham, L. Zeringue, D. Wilson, and D. Babcock. 1983-1984. Effects of forage minerals on reproduction of Holsteins. La. Agric. 27(2):17-19.

7. Kleese, R.A., D.C. Rasmusson, and L.H. Smith. 1968. Genetic and environmental variation in mineral element accumulation in barley, wheat, and soybeans. Crop Sci. 8:591-593.

8. Knudsen, D., R.B. Clark, J.L. Denning, and P.A. Pier. 1981. Plant analysis of trace elements by $x$-ray. J. Plant Nutr. 3:6175 .

9. Pedersen, J.F. 1981. Variability for forage quality, silage quality, and agronomic traits in forage sorghum. Ph.D. diss. Univ. of Nebraska, Lincoln (Diss. Abstr. 81-20168).

10. ---, H.J. Gorz, F.A. Haskins, and W.M. Ross. 1982. Variability for quality and agronomic traits in forage sorghum hybrids. Crop Sci. 22:853-856.

11. ----, F.A. Haskins, H.J. Gorz, and R. Britton. 1983. Variability for traits used to estimate silage quality in forage sorghum hybrids. Crop Sci. 23:376-379.

12. Reid, R.L., and G.A. Jung. 1974. Effects of elements other than nitrogen on the nutritive value of forage. p. 395-435. In D.A Mays (ed.) Forage fertilization. American Society of Agronomy, Crop Science Society of America, and Soil Science Society of America, Madison, WI.

13. Ross, W.M., H.J. Gorz, F.A. Haskins, G.H. Hookstra, J.K. Rutto, and R. Ritter. 1983. Combining ability effects for forage residue traits in grain sorghum hybrids. Crop Sci. 23:97-101. 